\title{
WHAT DRIVES CONSUMERS SMART? THE CHALLENGE OF ADOPTION OF SMART CITY SOLUTIONS
}

\author{
YU.A. MALCHENKO, M.M. SMIRNOVA \\ Graduate School of Management, St. Petersburg State University
}

\begin{abstract}
Following increasing usage of digital technology-based solutions, many cities pushed the concept of smartness for efficient utilisation of limited resources. Smart cities require close collaboration between the city governance, business, and consumer communities to develop solutions for various circles of stakeholders. While most of studies in this field focused on digital technology, the importance of citizen-centric approach has gathered the momentum. However, there is a lack of research on adoption of smart city solutions by citizens. In practice, while consumer feedback was proposed, factors enhancing consumer willingness to adopt smart city solutions were not identified. This study aims to propose a framework by introducing an integrative citizen-centric bottom up approach based on consolidation of insights from literature dedicated to innovation adoption and smart city solutions. The suggested framework is accompanied by propositions for future research focusing on digital natives as future consumers of smart solutions.
\end{abstract}

Keywords: smart city solutions, innovation adoption, consumer adoption, willingness to adopt, citizen-centric approach, bottom-up approach.

JEL: M31.

With changes in socio-economic factors and growth in urban population worldwide, there has been an increase in dependence on technological advancement to efficiently utilise the limited resources. This trend re- sulted in the inception of the smart cities (SC). Although the interest to study smart city topic engendered a couple of decades ago, it gained momentum around 2011-2012 [Camero, Alba, 2019]. Based on the IESE

This research has been conducted with financial support of St. Petersburg State University (project No. 40940187).

Postal Address: St.Petersburg State University, Graduate School of Management, 3, Volkhovskiy per., St.Petersburg, 199004, Russia.

(c) Yu. A. Malchenko, M. M.Smirnova, 2019

https://doi.org/10.21638/spbu18.2019.305 
Cities in Motion Index cited by Forbes [Forbes, 2018] there exist around thirty smart cities, and according to IHS Markit Technology [IHS Markit, 2014] by 2025 eighty eight smart cities will have put themselves on the map. New York, the leading smart city [Forbes, 2018] in the world, has launched a strategy OneNYC 2050 [OneNYC 2050, 2019], "Smart Dubai" [Aina, 2017] has implemented a constellation of smart projects; Moscow and Saint Petersburg, (Russia) have pioneered their way to smartness - this is merely a few smart city projects currently in progress around the globe.

Interestingly, it was not until May 2019 when an international standard [ISO, 2019] established definition and indicators for smart cities. Prior to that, cities would self-claim their smartness [Anthopoulos, 2017] according to their own definitions of smart city, which reflects an incipient nature of the phenomenon. The definition given in the aforesaid ISO/DIS is comprehensive, representing the multifaceted nature of the concept with various dimensions and stakeholders: smart city is the one that "increases the pace at which it provides social, economic, and environmental sustainability outcomes, deals with challenges such as climate change, rapid population growth, political and economic instability by fundamentally improving how they engage society, apply collaborative leadership methods, work across disciplines and city systems, and use data information and modern technologies to deliver better services and quality of life to residents, businesses, visitors, now and for the foreseeable future, without unfair disadvantage of others or degradation of the natural environment" [ISO, 2019].

The outlined in the definition multidimensional nature of SC has been reflected in academia: smart city topic has been discussed in journals majoring in societal science, economics, environment, transportation, energy, governance, management, bu- siness, and computer sciences. Most of the SC literature can be broadly categorized into techno-centric [Janowski, Estevez, Baguma, 2018; Yigitcanlar et al., 2018] and governance-oriented. Thus, smart solution providers (companies, dealers, government) impose such adoption for corporate and economic reasons [Trencher, 2019]. Nevertherless, consideration of SC as a "forthcoming dominant market" reaching $\$ 3$ trillion U.S. by 2020 [Anthopoulos, 2017, p. 128] explicitly highlights the importance of focus on communicating and fostering adoption of SC solutions.

Surprisingly, despite the abovementioned, there has been a limited effort to specifically focus on the issue of adoption of SC solutions. The need in citizen-centric approach is highlighted merely by few academic researchers [Lee, Lee, 2014; Fernandez-Anez, Fernández-Güel, Giffinger, 2018], as well as practical researchers [Woetzel, Kuznetsova, 2018]. Although the extant research of $\mathrm{SC} /$ smart solutions provided their solid classifications, it has not aligned them with the bottom-up approach consumers' (un-) willingness to adopt these solutions. In reality, smart city projects, such as Korean Songdo City, despite having been in progress for the last couple of decades still have not reached the desired results [Yigitcanlar et al., 2018]. The reluctance from the citizens' side to adopt the SC solutions aimed at improving their lives has been highlighted in reports by McKinsey [Woetzel, Kuznetsova, 2018]. Innovation adoption literature provides classification of innovations based on the level of comprehensiveness: innovations in general [Rogers, 2003] or, for instance, ubiquitous information systems in particular [Prensky, 2001; Vodanovich, Sundaram, Myers, 2010]. The innovations embodied into SC solutions require understanding of consumers and their needs. Our study endeavours to bridge this gap by offering an integrative perspective that intertwines 
typology of smart services with bottom-up citizen-centric approach and characteristics of consumers into a unified framework.

The aim of this article is to review and systematize existing academic approaches to SC concept, to offer the citizen-centric bottom-up approach towards smart solution categories given consumer characteristics and to develop an integrated typology of the smart solutions. The intended contributions of the research is a novel integrated typology of smart solutions through a bottom-up citizen-centric approach with regard to the types and dimensions of innovations and characteristics of consumers, as well as built on the typology propositions suggested for future research in the field of consumer adoption of SC solutions.

The remainder of the paper is divided into three sections. The first section provides the methodology and key assumption of the literature review. The second section reviews extant approaches to SC conceptualization and introduces a typology of solutions with regard to the bottom-up citizen-centric approach and suggests avenues for future research in the form of propositions. Finally, the third section draws conclusions and outlines limitations of the research.

\section{Methodology of Literature Search}

Systematic search of literature was conducted in Scopus database among journals recognised world-wide and ranked as $4 \%$, 4 and 3 by the Association of Business Schools. The relevant articles were selected based on the keywords "adoption", "acceptance" with conjunction of "smart city solutions" and their derivatives yielded results mainly focused on alternative fuel vehicles [Chorus, Koetse, Hoen, 2013; Jensen, Cherchi, Mabit, 2013; Li, Gordon, Gelfand, 2017], which according to [Kumar et al., 2018] are within the smart city scope, or Internet of Things (IoT) and Information and Communication Technologies (ICT) [Chatterjee, Kar, Gupta, 2018; Wirtz, Weyerer, Schichtel, 2018; Yeh, 2017]. Since only few articles could be found related to adoption of SC solutions specifically, we conducted the search of relevant articles in two stages. In the first stage we analysed 101 articles related to adoption of innovations by consumers in general using keywords "innovation adoption", "innovation acceptance". In the second stage 57 articles using keywords "smart city", "smart city solutions" and their derivatives, were retrieved. From 5 factors of adoption typically discussed in consumer behavior literature (i.e. behavior intention, consumer outcome, motivation, opportunity and ability), we focused on motivation only. Details of motivational factor identified from the literature are placed in Appendix.

We grouped the extant source on SC based on technology used, namely ICT, IoT and Artificial Intelligence (AI), as well as following a recent focus on sustainability, additional sources were added into analysis. As it can be seen from Table 1, technology is shifting from adaptive to predictive (ICT to AI). Thus, SC of future should also be based on predictive (citizen-centric) rather than present generation adaptive (supplierbased) solutions. Further, sustainability is also gaining the momentum.

The majority of the proposed definitions encapsulates the concepts of "a holistic vision of subfields" [Camero, Alba, 2019, p.93], importance of information technology, citizens being targeted in the first place, availability of open data, and sustainability. The commonly cited smart city definitions by [Camero, Alba, 2019] focused on citizens and smart solutions, infrastructure resources, human capital, high technologies, and ICT. The approach adopted was either technology driven or human driven or a combination of both (Table 2).

Intuitively, the reasons of why consumers are slow in adopting digital technology- 
Table 1

Type of technology focus in the literature in Scopus database, 2016-2019

\begin{tabular}{c|c|c|c|c}
\hline Number of articles as per years & ICT & IoT & AI & Sustainability \\
\hline 2016 & 9 & 2 & - & 2 \\
\hline 2017 & 7 & 3 & - & 3 \\
\hline 2018 & 8 & 21 & - & 5 \\
\hline 2019 & 4 & 9 & 3 & 6 \\
\hline
\end{tabular}

Notes : search criteria in Scopus database: 2016-2019; "smart city" OR "smart cities" AND "smart technology" AND "ICT"; "smart city" OR "smart cities" AND "smart technology" AND "IoT"; "smart city" OR "smart cities" AND "smart technology" AND "AI"; "smart city" OR "smart cities" AND "smart technology" AND "sustainability".

Table 2

Overview of smart city definitions, their focus and approach

\begin{tabular}{|c|c|c|c|}
\hline Author & Definition & Focus & Approach \\
\hline $\begin{array}{l}\text { [Hall et } \\
\text { al., } 2000 \\
\text { p. 2] }\end{array}$ & $\begin{array}{l}\text { "A city that monitors and integrates conditions of all of its } \\
\text { critical infrastructures, including roads, bridges, tunnels, } \\
\text { rails/subways, airports, seaports, communications, water, } \\
\text { power, even major buildings, can better optimise its resources, } \\
\text { plan its preventive maintenance activities, and monitor secu- } \\
\text { rity aspects while maximizing services to its citizens... systems } \\
\text { and structures will monitor their own conditions and carry out } \\
\text { self-repair, as "needed"” }\end{array}$ & $\begin{array}{l}\text { Infra- } \\
\text { structure } \\
\text { and resourc- } \\
\text { es }\end{array}$ & $\begin{array}{l}\text { Technology- } \\
\text { driven }\end{array}$ \\
\hline $\begin{array}{l}\text { [Harrison } \\
\text { et al., } \\
2010, \\
\text { p. } 1-2]\end{array}$ & $\begin{array}{l}\text { "Connecting the physical infrastructure, the IT infrastructure, } \\
\text { the social infrastructure, and the business infrastructure to } \\
\text { leverage the collective intelligence of the city" }\end{array}$ & $\begin{array}{l}\text { Infra- } \\
\text { structure }\end{array}$ & $\begin{array}{l}\text { Technology- } \\
\text { driven }\end{array}$ \\
\hline $\begin{array}{l}\text { [Caragliu, } \\
\text { Del Bo, } \\
\text { Nijkamp, } \\
2011 \\
\text { p. } 50]\end{array}$ & $\begin{array}{l}\text { "We believe a city to be smart when investments in human and } \\
\text { social capital and traditional (transport) and modern } \\
\text { (Information and Communications Technology, ICT) communi- } \\
\text { cation infrastructure fuel sustainable economic growth and a } \\
\text { high quality of life, with a wise management of natural } \\
\text { resources, through participatory governance" }\end{array}$ & $\begin{array}{l}\text { Human } \\
\text { capital and } \\
\text { infra- } \\
\text { structure }\end{array}$ & $\begin{array}{l}\text { Human- } \\
\text { driven and } \\
\text { technology- } \\
\text { driven }\end{array}$ \\
\hline $\begin{array}{l}\text { [Manville } \\
\text { et al., } \\
2014, \text { p.9] }\end{array}$ & $\begin{array}{l}\text { "A Smart City is a city seeking to address public issues via } \\
\text { ICT-based solutions on the basis of a multi-stakeholder, munici- } \\
\text { pally based partnership" }\end{array}$ & $\begin{array}{l}\text { ICT and } \\
\text { multi-stake- } \\
\text { holders }\end{array}$ & $\begin{array}{l}\text { Technology- } \\
\text { driven and } \\
\text { human-driven }\end{array}$ \\
\hline $\begin{array}{l}\text { [Giffinger } \\
\text { et al., } \\
2007, \\
\text { p.11] }\end{array}$ & $\begin{array}{l}\text { "A Smart City is a city well performing in a forward-looking } \\
\text { way in these six characteristics [smart economy, smart people, } \\
\text { smart governance, smart mobility, smart environment and } \\
\text { smart living], built on the "smart" combination of endowments } \\
\text { and activities of self-decisive, independent and aware citizens" }\end{array}$ & $\begin{array}{l}\text { Citizens and } \\
\text { smart } \\
\text { solutions }\end{array}$ & $\begin{array}{l}\text { Human- } \\
\text { driven and } \\
\text { technology- } \\
\text { driven }\end{array}$ \\
\hline $\begin{array}{l}\text { [Dameri, } \\
2013, \\
\text { p. } 2549]\end{array}$ & $\begin{array}{l}\text { "A smart city is a well-defined geographical area, in which high } \\
\text { technologies such as ICT, logistic, energy production, and so } \\
\text { on, cooperate to create benefits for citizens in terms of well- } \\
\text { being, inclusion and participation, environmental quality, } \\
\text { intelligent development; it is governed by a well-defined pool of } \\
\text { subjects, able to state the rules and policy for the city govern- } \\
\text { ment and development" }\end{array}$ & $\begin{array}{l}\text { High } \\
\text { technologies }\end{array}$ & $\begin{array}{l}\text { Technology- } \\
\text { driven }\end{array}$ \\
\hline
\end{tabular}

S o u r ce: adapted from [Camero, Alba, 2019].

PЖM 17 (3): 387-410 (2019) 
related smart solutions can be referred to digital divide. However, since it is related to exogenous reasons specific to socio-economic factors [Goncalves, Oliveira, CruzJesus, 2018], we leave this concept outside the scope of our research. Instead, we will focus on the challenge of adoption of digital solutions with the assumption that the access to them has been granted - a "second order digital divide" [Goncalves, Oliveira, Cruz-Jesus, 2018, p.277].

\section{Approaches to SC Conceptualisation}

As brought out above, according to the extant literature SC concept took the approach either technology-driven or humandriven or their combination. This division resulted in grouping researchers into prosmart city or anti-smart city camps. An overview of existing studies results in general in the following typology, based on criteria of being technology vs. himandriven, pro vs. anti-smart city, as well as additional categorisation based on prioritizing product vs. service, and categories of adopters:

- technology-driven vs. human-driven approaches: the distinction between the approaches is based on technology or citizen centricity in the architecture of SC/smart solutions;

- technology-driven vs. technology \& human-driven vs. human driven approaches: introduction of a transition point between technology and human approaches which provides smoother shift between the two sides of the continuum by linking the two abovementioned approaches;

- pro-smart city vs. anti-smart city approaches: the distinction is based on the attitude towards the SC concept and its focuses;

- division of approaches based on smart categories - e.g. smart products vs. smart services vs. smart technology in- tertwined with the human-driven approach.

The above mentioned approaches are critically analysed and compared in the sections below.

\section{Technology-driven and human-driven approaches to $S C$}

According to [Kummidha, Crutzen, 2018], one of the first classifications suggests differentiation between technology-driven and human-driven approaches to SC (Table 2). The validity of this approach demonstrating the distinction between the two approaches to the SC concept is acknowledged by the recent definitions placed in Table 3.

This classification is in line with the prosmart city Restrictive school of thought specified in the corresponding section below.

Technology-driven, technology \& humandriven, and human-driven approaches to $S C$

However, along with the technology centricity certain authors emphasize the importance of various stakeholders in general [Manville et al., 2014; Caragliu, Del Bo, Nijkamp, 2011] and citizens in particular [Giffinger et al., 2007], therefore, establishing a transition between technology- and human-driven definitions: the smart city as a concept of six dimensions - smart economy, smart people, smart governance, smart mobility, smart environment and smart living [Giffinger et al., 2007]. This leads to a more comprehensive categorisation of approaches towards SC solutions into technology-driven, human \& technology-driven and human-driven. Such a transition point where the focus on technology and citizens is equally important can be identified as a hybrid approach and can be considered for designing and implementing SC initiatives. This categorisation complies with the prosmart city Reflective school of thought outlined below. 
Table 3

\section{Recent approaches to SC concept definition}

\begin{tabular}{|c|c|c|}
\hline \multirow{2}{*}{ Definition } & \multicolumn{2}{|c|}{ Approach } \\
\hline & Technology-driven & Human-driven \\
\hline $\begin{array}{l}\text { "A humane smart city addresses first of all people and their needs. } \\
\text { Then comes technology and only in direct connection with these needs" } \\
\text { [Costa, Oliveira, 2017, p. 228] }\end{array}$ & & + \\
\hline $\begin{array}{l}\text { "The smart city is defined as the one that "takes advantages of the } \\
\text { opportunities offered by ICT in increasing local prosperity and com- } \\
\text { petitiveness - an approach that implies integrated urban development } \\
\text { involving multi-actor, multi-sector and multi-level perspectives"” } \\
\text { [Ruhlandt, 2018, p.407] }\end{array}$ & + & \\
\hline $\begin{array}{l}\text { "[...] a central tenet of "smart cities" is the use of ICT to address one } \\
\text { or more sustainability issues, improve the e ciency of urban services, } \\
\text { and contribute to the economic competitiveness and liveability of } \\
\text { cities" [Van den Buuse, Kolk, 2018] }\end{array}$ & + & \\
\hline $\begin{array}{l}\text { "Smart city is not a top-down developmental process but a bottom-up } \\
\text { emergence phenomenon" [Chong et al., 2018, p. 682] }\end{array}$ & & + \\
\hline $\begin{array}{l}\text { "Today, smart cities are seen as the hubs of technological innovation } \\
\text { [...]" [Yigitcanlar et al., 2018, p. 146] }\end{array}$ & + & \\
\hline
\end{tabular}

\section{Pro-smart city and anti-smart city approaches to $S C$}

Regarding the existing conceptualization of three schools of thought: restrictive, reflective, rationalistic [Kummitha, Crutzen, 2017], we suggest identifying them as pro-smart city approaches, as opposed to anti-smart city or critical school of thought (Figure 1). Technology-driven approach is reflected in the core agenda of the restrictive school: the adoption of technologies, particularly, IoT and their incorporation into the urban infrastructure. The proclivity of reflective school towards the usage of technologies for improving human lives is in line with the abovementioned transition concept. The rationalistic school focuses on people and their capabilities, which makes it close to the human-driven approach. However, the critical school of thought critiques existing approaches to the city development for various reasons, among which is the "wedding" of suppliers and governments, which "leaves out real community problems" [Anthopoulos, 2017, p. 128] or the fact that smart cities prac- tice a top-down approach as an outcome of the aggressive push of major global firms [Yigitcanlar et al., 2018]. The governance focus towards SC technologies indeed has been one of the major focuses within the range of selected articles. The former critique can be tackled by the rationalistic school - investment in citizens' learning and involvement in the solutions of the urban problems [Kummitha, Crutzen, 2017], which constitutes bottom-up approach corresponding to the citizen-centric one mentioned by the McKinsey report [Woetzel, Kuznetsova, 2018].

\section{Introduction of novel typology of SC solutions}

Thus, summing up previous findings, based on systematic critical analysis of extant research, the identified approaches were classified into three main groups of SC approaches the first one opposes technology-driven and human-driven approaches to SC; the second one additionally identifies a mixed technology \& human-driven approach; and finally, the third one confronts pro-smart 


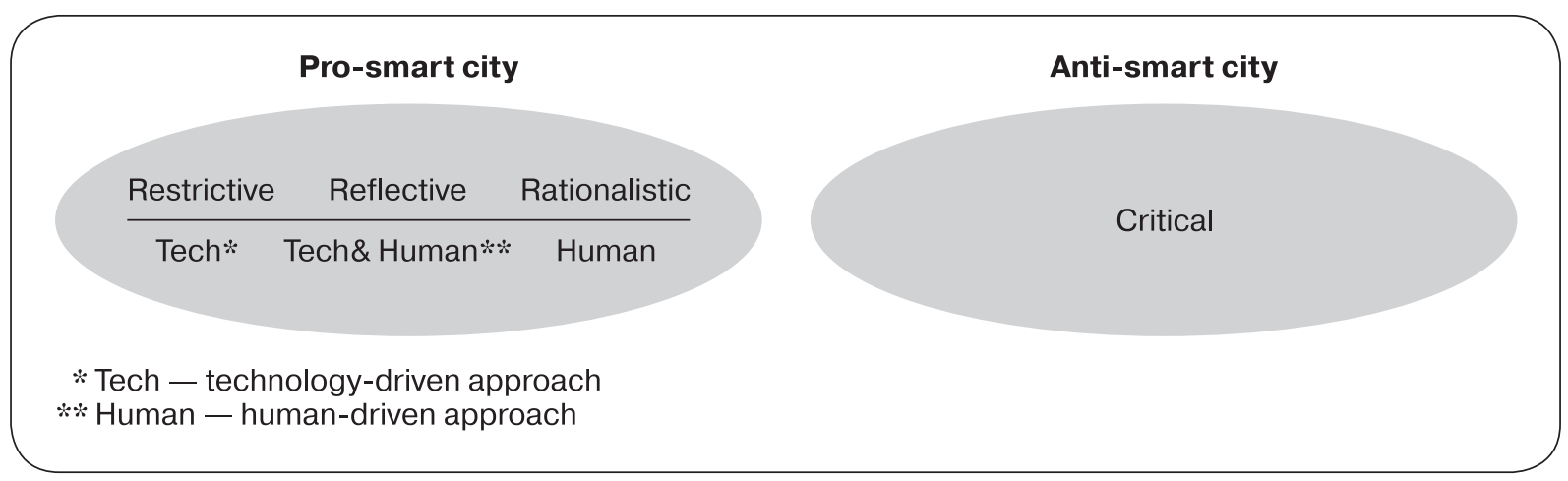

Figure 1. Schools of thought and approaches in smart city literature S o u r c e: based on [Kummitha, Crutzen, 2017].

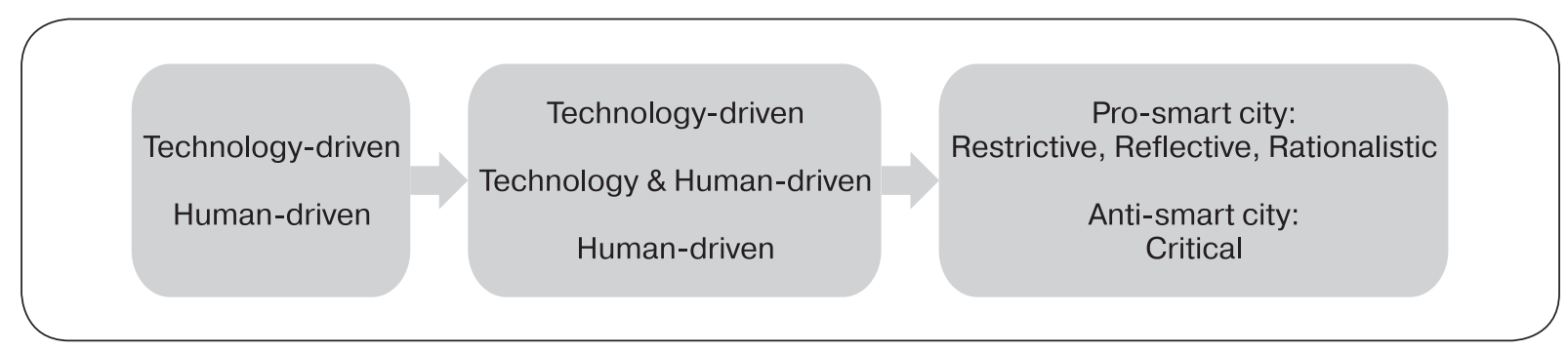

Figure 2. Extant classifications of approaches to SC

city and anti-smart city approaches, while integrating several schools of thought (Figure 2).

This paper tries to merge technology focus relevant for Restrictive school of thought with the concept of human centricity [Lee, Lee, 2014] pertaining to the Rationalistic school. Based on such a combination, we propose an approach for the fourth classifications of SC solutions implying market categories given their adoption by consumers: smart services, smart products, and smart technologies (Figure 3).

From the perspective of consumer adoption of categories offered by the market, smart solutions can be classed into smart service, smart product, and smart technology.

Smart categories: smart service, smart product, and smart technology

According to [Allmendinger, Lombreglia, 2005] manufacturers are at a loss if they offer a product without converting it into a service, particularly a smart service: "Any industrial manufacturer that has not awakened to the fact that it must become a service business is in serious peril today" [Allmendinger, Lombreglia, 2005]. Furthermore, [Anthopoulos, 2017] introduced the yardsticks for a city to claim itself smart, which concern mobile services or applications. According to various studies, smart cities mostly offer services and service-based apps [Lee, Hancock, Hu, 2014; Lim, Kimb, Maglioc, 2018].

Regarding smart products, [Porter, Heppelmann, 2014] suggested the term "connected products" and decomposed them into three core elements: physical, "smart", and connectivity components. While smart components amplify the capabilities and value of the physical components, connectivity boosts the capabilities and value of the smart components and enables their existence outside the physical product. The criterion of calling the product smart and 


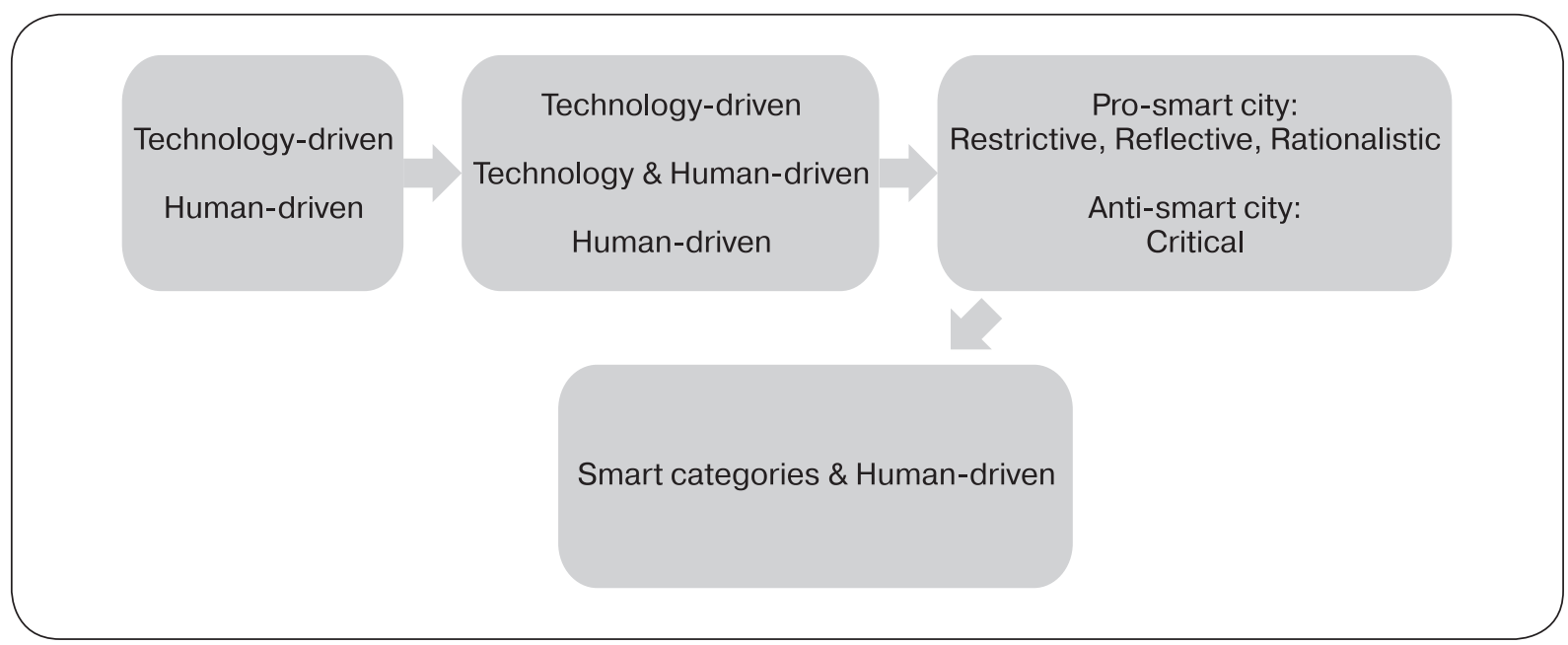

Figure 3. Classification of SC approaches with a novel original approach (smart categories and human-driven)

connected rests on the changing nature of the "things", rather than the internet. They can function autonomously under the supervision of operators over the whole pool of solutions, rather than an individual one. Companies are advised to look beyond the technologies themselves towards the competitive transformation [Porter, Heppelmann, 2014].

Extant literature showed two ways to regard smart technology: as a tool for smart initiative (e.g. ICT), and as a smart product (e.g. eco-digital LED technology, IoT) (Table 4). Technology side includes data centers, internet infrastructure, endpoints (sensors and others) [Wirtz, Weyerer, Schichtel, 2018]. McKinsey [Woetzel et al., 2018] report examines dozens of technologies as an outcome of SC in the domains of security, healthcare, resources, waste, mobility, economic development, housing, community and engagement, and suggested the yardsticks to call technologies smart: digital and/or data-based nature of technologies aiming at addressing a public problem related to sustainability in one way or another, and a necessity of cities to play a major role in the adoption of such technologies. A few key technologies are contributing to the urban sustainability but do not satisfy the abovementioned criteria. One of them is alternative fuel vehicles, for instance, which is not digital or data-based [Woetzel et al., 2018].

Since smart services include ICT, might comprise IoT and to be considered when providing smart products [Allmendinger, Lombreglia, 2005], as well as taking into account the position of smart services in the density cloud introduced by [Lim, Kimb, Maglioc, 2018], smart services stand out in the range of categories and occupy a special position in SC, hence we will explore them in detail.

\section{Human-driven approach towards smart solutions}

The consumer centricity discussed in literature is related to the smart solutions nature and the very characteristics of their key consumers - citizens of smart cities.

The citizen-centric approach in categorisation of smart services has been captured in the study by [Lee, Lee, 2014]. Table 5 presents the characteristics of citizen-centric typology of smart cities.

While the first three dimensions appear to be intuitively clear, the fourth one, 
Smart technology concept

\begin{tabular}{l|l|l}
\hline Classification & $\begin{array}{l}\text { Technology as a tool for } \\
\text { smart initiative }\end{array}$ & Technology as an outcome of smart initiative \\
\hline Example & $\begin{array}{l}\text { ICT, digital technologies, } \\
\text { open public data }\end{array}$ & $\begin{array}{l}\text { Eco-digital LED technology, IoT, AI, environmentally-bene- } \\
\text { ficial technology, green technology, sustainable technology }\end{array}$ \\
\hline
\end{tabular}

S o u r c e: based on [Lee, Park, Lee, 2018; Bollinger, Gillingham, 2012; Graham-Rowe et al., 2012; Wirtz et al., 2018; Lim et al., 2018; Sun, Medaglia, 2019; Hall et al., 2000].

Table 5

Citizen-centric typology of smart services

\begin{tabular}{l|l|l}
\hline \multicolumn{1}{c|}{ Characteristic } & \multicolumn{1}{c}{ Definition } & \multicolumn{1}{c}{ Categories } \\
\hline Mode of technology & $\begin{array}{l}\text { How ICT changes the shape of } \\
\text { services }\end{array}$ & $\begin{array}{l}\text { Automate vs. Informative } \\
\text { vs. Transformative }\end{array}$ \\
\hline Service purpose & $\begin{array}{l}\text { What is the purpose of the } \\
\text { service }\end{array}$ & Hedonic vs. Utilitarian \\
\hline Service authority & $\begin{array}{l}\text { How autonomous are citizens } \\
\text { in using service }\end{array}$ & Voluntary vs. Mandatory \\
\hline Delivery mode & $\begin{array}{l}\text { How services are being } \\
\text { delivered }\end{array}$ & Passive vs. Interactive \\
\hline
\end{tabular}

S o u r c e: based on [Lee, Lee, 2014].

namely passive vs. interactive delivery mode needs to be clarified separately. According to [Lee, Lee, 2014], passive services are those "processed without the need to obtain any feedback from service consumers" [Lee, Lee, 2014, p. 598]. The interactive one, on the contrary, is meant to obtain such a feedback. Various combinations of modes of technology, service purpose, service authority and delivery mode are applied in existing services. Thus, smart metering [Chatfield, Reddick, 2018] could be an example of the combination AutomateUtilitarian-Mandatory-Passive (AUMP), as well as Automate-Utilitarian-VoluntaryPassive (AUVP) as it has been implemented in Saint Petersburg, Russia. However, according to [Lee, Lee, 2014] automate mode of services should be related to AUMP, not AUVP [Lee, Lee, 2014]. The suggestion can explain the incidence of certain reluctance from the Saint Petersburg citizens' side to uptake smart meters which provide the automate value for consumers. From the citizen-centric bottom-up lens the following categories can be outlined: IHVI, IUVI, THVI, and TUVI.

Since smart services tend to solve the current public utilitarian problems, the hedonic purpose might also be part of such a service, providing information or totally transforming the way the service was rendered before. For instance, a waste disposal system which transforms the way citizens dispose electronic gadgets can be incorporated in the portal where people indicate what they want to discard which can be further picked up. Those who dispose their waste via the portal receive credit points which can be used as discounts for new products. Collected items can be reused/ partially used or centrally recycled/disposed. The hedonic purpose of receiving the points for acquiring something in return 
Table 6

Converged smart services typology based on bottom-up citizen-centric and innovation type perspective

\begin{tabular}{c|cc|cc}
\hline Dimension & \multicolumn{3}{|c}{ Combinations of categories } \\
\hline Technological & Informative & \multicolumn{2}{c}{ Transformative } \\
& Hedonic & Utilitarian & Hedonic & Utilitarian \\
\hline Organizational & Informative & Transformative \\
& Utilitarian & Utilitarian \\
\hline Collaborative & \multicolumn{3}{|c}{ Voluntary } \\
& \multicolumn{3}{|c}{ Interactive } \\
\hline Experimental & Informative & Transformative \\
& Hedonic Utilitarian & Hedonic & Utilitarian \\
\cline { 2 - 4 } & \multicolumn{3}{|c}{ Voluntary } \\
& \multicolumn{3}{|c}{ Interactive } \\
\hline
\end{tabular}

S o u r c e: based on [Lee, Lee, 2014; Nilssen, 2018].

can instigate the citizens engagement leading to their adoption. The idea of taking into account the mentioned in the typology features are further elaborated in propositions for future research in the same-name section (vide section dedicated to propositions).

Despite reflecting the categorical characteristics of the smart services, the abovementioned typology tends to overlook the extent and types of innovations those services represent. The classification suggested by [Nilssen, 2018] address the mentioned aspects by outlining four dimensions of innovation: (1) technological; (2) organizational; (3) collaborative; (4) experimental. Whilst technological innovations include new practices, products, and services, organizational innovations embrace innovations introduced internally within firms. Collaborative innovations require public-private networks. And, finally, experimental innovations imply innovative urbanism as a vision [Nilssen, 2018]. We further converge those dimensions with the typology by [Lee, Lee, 2014] (Table 6). The mode of technology by [Lee, Lee, 2014] is in line with the technological dimension of the innovation. The organizational dimension is lacking in Lee and Lee's citizencentric typology which is logical since it appears to be outside the scope of the classification. However, since those innovations are introduced within the company, they barely can be hedonic. Hence, the difference between organizational and technological dimension of innovation is an absence of hedonic dimension in the former. Collaborative dimension complies with the voluntary service authority and interactive delivery mode by [Lee, Lee, 2014]. Experimental dimension combines the whole range of categories mentioned in Table 5.

This original typology reflects the citizen-centric trend existing in practice where citizens consider themselves as pro-active participants in mitigating urban problems, which is confirmed by statistics. Particularly, Moscow's governmental portal 'Our city' (gorod.mos.ru) in 2017 registered 839.2 thousand claims related to public problems from the citizens, which resulted in elimination of $85 \%$ of the public prob- 
lems. The typology accentuates the nature of solutions in which the citizens can be engaged in various dimensions of the entire scope of SC activities. The suggested typology can be used for further empirical research verifications of the underlying factors of adoption so that it can be deployed by practitioners as guidance to act on while endeavouring activities in the smart city concept (vide propositions in the corresponding section below).

The offered novel typology, being citizencentric, can be supplemented or relooked based on the approaches to the consumer categorisation. The paper further proceeds to analyzing the tendency existing in academia pertaining to the consumers of SC solutions as those which deploy digital and data-based solutions.

\section{Human-driven approach: categorisation of SC citizens}

Since smart city solutions are regarded as the digital and data-based ones with the aim of addressing a public problem in a city [Woetzel et al., 2018], we proceed with the specific classification of consumers (citizens) related to digitization, namely digital natives and digital immigrants [Prensky, 2001]. Digital immigrants are adapting to the new environment of ubiquitous ICT, whilst the digital natives require it. According to [Vodanovich, Sundaram, Myers, 2010] there exists a plenty of research related to digital immigrants and their adaptation to the new digital environment, while scant research is dedicated to digital natives [Vodanovich, Sundaram, Myers, 2010]. Since smart city is "a strategic vision to reach sustainable futures, rather than a description of reality in a current context" [Kummitha, Crutzen, 2017, p.44], the focus on digital natives in the smart city context represents the perspective direction for future research. For digital natives, interactivity, usability, flexibility, and connectivity are as important as func- tionality [Vodanovich, Sundaram, Myers, 2010]. This is in line with the classification of the smart services given in Table 6 requires no further adjustment of the offered typology.

The suggested typologies in Table 6 can be used as a starting point for researchers who focus on the topic of adoption of SC solutions as well as practitioners who would like to implement smart city projects. It can also be used as the basis for identifying the avenues for future research. The article further proceeds to such propositions which can be verified empirically to provide specific guidelines for practitioners and acknowledges the relevance of the proposed typologies.

\section{Human-driven approach: propositions pertaining to adoption of SC solutions by digital natives}

As it was explicitly indicated in the offered typology in Table 6 , the purpose of the smart solution can be subdivided into hedonic and utilitarian ones. These purposes can be considered potentially matching the intrinsic and extrinsic consumer motivations to adopt those smart solutions. Moreover, the collaborative and experimental dimensions of SC innovations correlate with interactive and proactive nature of consumers. From the adoption perspective, the predominant utilitarian nature of smart solutions can be subject to elaborating the ways how to reinforce adoption by the digital natives as core consumers. By extending the purpose dimensions of innovations suggested in Table 6 , and focusing on digital natives, the paper further proposes for empirical verifications the ways how to entice digital natives to actively adopt the SC/ smart solutions.

Regarding the preference of digital natives towards playing games rather than working, an interesting question would be how the introduction of the hedonic component to the utilitarian services can 
increase their adoption by digital natives. In this case the urban concern can be addressed with the aid of games. For instance, a gamified app tracking the waste recycling gathered by a person, which would disseminate the information to the other app users as part of a contest is likely to increase the interest of digital natives to participate in such an activity. The tendency of gamified deed in favour of public is being empirically observed by the authors of the article at such event as Clean Games, where participants collect and separate trash for recycling and the jury announces the winner based on the gathered amount of rubbish within a period of time. The event gathered some 48 thousand of volunteers all over the world, majority of them being digital natives - mainly millennials ${ }^{1}$. This approach combines two types of motivation: extrinsic, when there is a particular purpose in the deed to be done, and intrinsic, when the actions are done for fun and enjoyment [Kumar et al., 2018]. Thus, we can provide first proposition.

Proposition 1: Introduction of hedonic component to the utilitarian smart solutions increases willingness of their adoption by digital natives.

Interactive and voluntary features of smart solutions comply with the nature of digital natives who perceive the ICT as an integral part of their lives (voluntary nature) and along with functionality and usability, demand flexibility and interactivity from it. Since digital natives perceive ICT as ubiquitous technology they dwell, work and play, they tend to create the content themselves [Vodanovich, Sundaram, Myers, 2010]. Hence, granting them authority through interactive voluntary engagement, which will show the flexibility and usability

${ }^{1}$ Based on the photographs of the events https://cleangames.ru/about (accessed: 25.09 . 2019). of the system, can stimulate their interest in such innovations.

Proposition 2: Interactive and voluntary nature of smart solutions augments the probability of their adoption by digital natives.

Moreover, for engagement of digital natives, a collaborative interaction can be deployed [Nilssen, 2018; Ruhlandt, 2018]. Collaboration with digital natives in the innovations has a three-fold effect. First, collaboration with firms will immerse the digital natives into the joint creation and interactivity, which can take a form of crowdsourcing, and, therefore, subsequently will likely lead to the adoption of the resulted outcome by those involved in such collaboration. Second, such collaboration can help companies to learn from the crowd [Nagle, 2018]. Third, digital natives based on their mindset - fixed or growth [Mathur, Chun, Maheswaran, 2016] - will either signal the result of their collaboration to others for seeking appreciation, and, therefore, will proliferate the collaboration outcomes, or will likely continue such a practice if the process has been enjoyable. Anyway, the outcome of such collaboration is envisaged to be positive for companies.

Proposition 3: Collaboration of digital natives with firms can increase adoption of the outcomes of such collaboration.

Digital natives can be further categorised into influentials and influenciables [Watts, Dodds, 2007]. Counter intuitively, the majority of influence is induced not by influentials but by easily influenced individuals [Watts, Dodds, 2007]. In the collaboration schema influentials are likely to be experts. Since experts have difficulties understanding and appreciating discontinuous innovations [Moreau, Lehmann, Markman, 2001], collaboration will help them understand and subsequently adopt smart innovations, which may or may not be discontinuous. Nowadays, some experts have their followers who can be roughly

PЖM 17 (3): 387-410 (2019) 
referred to easily influenciable since they follow those experts. Although a relatively large number (which we would call decent) of followers of those experts does not guarantee adoption by all of them, it can increase the chances of such adoption. Thus, engaging the experts who have a decent number of followers is foreseen to tackle the issue of subsequent adoption of the collaboration results.

Proposition 4: Involving experts with a decent number of followers into collaboration will result in adoption of the outcome of such collaboration by both the experts and the influenciables following them.

Since environmentally aware young residents - digital natives - are susceptible to sustainable solutions [Hackbarth, Madlener, 2013], the very notion of the solution being sustainable may lead to their favourable attitude towards it. Since SC solutions / smart solutions are commonly related to sustainability, the very notion of "smart" or "sustainable" as a brand [Lee, Lee, 2014] might instigate their adoption, apart from other motivations, such as homophily [Aral, Walker, 2011; Susarla, Oh, 2012; Haenlein, 2013; Goel, Goldstein, 2014; Morvinsky, Amir, Muller, 2017], signaling [Peres, Muller, Mahajan, 2010; Mathur, Chun, Maheswaran, 2016; Morvinsky, Amir, Muller, 2017], network externality [Peres, Muller, Mahajan, 2010; Aral, 2011; Haenlein, 2013], intrinsic and extrinsic motivation [Frey, OberholzerGee, 1997; Edinger-Schons et al., 2018; Kumar et al., 2018], word-of-mouth (WOM) [Peres, Van den Bulte, 2014; Bollinger, Gillingham, 2012; Godes, Mayzlin, 2004], including electronic WOM [So, Oh, Min, 2018], monetary incentives [Lambrecht, Seim, Tucker, 2011; Beresteanu, Li, 2011], social norms [Langley et al., 2012; Ariely, Gneezy, Haruvy, 2017] and others (for the overview of motivations vide Appendix).

Proposition 5: The notions 'smart' and 'sustainable' towards solutions influence their adoption by digital natives.
The abovementioned propositions based on the offered novel typologies of smart solutions (Table 5 and 6), although extend them and convert into testable grounds for academic endeavours, due to the space constraint of the article do not intend to cover all the aspects and implications which can be inferred from the mentioned typology. By suggesting avenues for future research, apart from introducing the content, the propositions demonstrate the relevance of the offered typology for conceiving such avenues.

\section{Conclusion}

The study aimed to bridge the gap in literature by considering SC solutions from the consumers and their adoption points of view by conducting a comprehensive analysis of approaches towards smart solutions, proposed the prospective classification of SC approaches, the citizen-centric bottomup typology of smart services, focus on digital natives as the principal consumers of smart city solutions, and offered the propositions for future research.

The paper outlines four classifications, building a continuum of their elements. The first classification is focused primarily on the technology- and human-driven approaches [Kummidha, Crutzen, 2017], whilst the second one adds a transition point to the aforesaid approaches, hence, indicating the necessity of shift towards human-centric approach [Giffinger et al., 2007; Caragliu, Del Bo, Nijkamp, 2011; Manville et al., 2014]. The third classification captures the abovementioned views into Restrictive, Reflective and Rationalistic schools of thought and introduces a Critical one, which we categorised as pro-smart city and anti-smart city correspondingly [Kummidha, Crutzen, 2017]. The final classification is offered to be smart solution-oriented based on their different categories (smart service, smart product, smart technology), 
hence implementing marketing perspective of adoption of the category with the regard to the consumer perspective, which is in line with Rationalistic school of thought, whilst capturing the technology components from Restrictive and the intertwining nature of Reflective ones. Such a classification partially takes into account the critiques by Critical school pertaining to the discrete, not consolidating nature of the SC initiatives [Kummidha, Crutzen, 2017]. Based on this classification the paper offered the integrated typology of smart city solutions based on citizen-centric bottom-up approach [Lee, Lee, 2014] and the extent and type of SC innovations [Nilssen, 2018] and characteristics of digital natives [Prensky, 2001; Vodanovich, Sundaram, Myers, 2010]. The typology distinguishes the following dimensions of SC solutions: technological dimension comprising informative and transformative nature of solutions having hedonic and utilitarian purposes organisational dimension which, comparing to the previous one, excludes the hedonic purpose; collaborative dimension which implies voluntary and interactive nature of solutions; and experimental dimension which encompasses all the above mentioned: informative and transformative mode of technology, hedonic and utilitarian purpose, voluntary authority and interactive delivery mode. This typology was then deployed conjointly with the traits of consumers - digital natives - as the ground for suggesting the avenues for future research and to demonstrate the relevance of such a typology as a building block for further studies. The offered propositions extend the typology with respect to the proclivity towards hedonic, interactive, and voluntary nature of innovations, mindset [Mathur, Chun, Maheswaran, 2016], association with influential and influenciables [Watts, Dodds, 2007] and attitude towards the "smart" and "sustainable" brand of smart solutions.
Theoretically, the research contributes to the marketing stream of research by systematizing existing classification of SC solutions proposing a new one from the marketing categorisation point of view, the integrative citizen-centric bottom-up typology of smart solutions, particularly, services given the type and extent of innovation they embody, and avenues for future research in the field of adoption of smart solutions by their prospective "heavy" users - digital natives. Managerially, the study outlines the areas to focus on while performing the research and development activities of smart solutions, involving citizens in those activities and launching SC solutions.

Despite the aforesaid contributions to research and management, this study has limitations. The literature search was predominantly performed in the Scopus reference database within top $(4 *, 4$, and 3$)$ ABS-ranking journals. This strategy may have overlooked potentially relevant articles from the analysis. However, the scope and quality of the selected articles assure the solid research foundation of the analysis. The other limitation is related to the focus of the suggested typology on the smart services, which might not be totally generalizable to smart product and smart technology, and, hence, can be taken into account while conducting future research. Due to the space constraint, the article could not reflect the exhaustive scope of prospects avenues for future research; however, the aim of suggested propositions, apart from their very content, is to demonstrate the relevance of the carved typology as a ground for future studies related to adoption of SC solutions.

\section{Acknowledgements}

We are grateful to Sergey A. Mityagin, Olga $\mathrm{N}$. Alkanova, and two anonymous reviewers for their valuable comments and guidance. 
Appendix

\section{MOTIVATION FOR ADOPTION OF PRODUCTS/TECHNOLOGY/SERVICES WITHOUT THE NOTION "SMART" OR "SUSTAINABLE"}

\begin{tabular}{|c|c|}
\hline Authors & Motivation for adoption \\
\hline 1 & 2 \\
\hline $\begin{array}{l}\text { [Morvinsky, Amir, } \\
\text { Muller, 2017] }\end{array}$ & Social influence, homophily to a large current adopting stock \\
\hline [Aral, Walker, 2011] & $\begin{array}{l}\text { Social influence (peer influence - WOM and social contagion - passive broadcast } \\
\text { notifications). Referrals, incentives for influentials to spread the word, viral } \\
\text { campaigns, viral product design. Homophily, pressure for conformity }\end{array}$ \\
\hline $\begin{array}{l}\text { [Peres, Muller, } \\
\text { Mahajan, 2010] }\end{array}$ & $\begin{array}{l}\text { Social interactions: network externalities, signals, interpersonal communications, } \\
\text { price reduction (associated with lower risk). Word of mouth and signalling across } \\
\text { countries }\end{array}$ \\
\hline $\begin{array}{l}\text { [Frattini et al., } \\
2014]\end{array}$ & Keeping up competitve \\
\hline [Greer, Lei, 2012] & $\begin{array}{l}\text { Individual, motivation for collaboration, demand for customization, trust, empa- } \\
\text { thy, peer recognition, high expectation of benefit }\end{array}$ \\
\hline $\begin{array}{l}\text { [Edinger-Schons et } \\
\text { al., 2018] }\end{array}$ & Intrinsic, extrinsic motives, self-signal, moral obligation \\
\hline $\begin{array}{l}\text { [Weaver et al., } \\
\text { 2015] }\end{array}$ & $\begin{array}{l}\text { Absolute (choosing the best - satisficer), relative standing (being the best - } \\
\text { maximiser) }\end{array}$ \\
\hline $\begin{array}{l}\text { [Ariely, Gneezy, } \\
\text { Haruvy, 2017] }\end{array}$ & Social norms (politeness, ethics), utility \\
\hline $\begin{array}{l}\text { [Beresteanu, Li, } \\
2011]\end{array}$ & Monetary (government tax programmes, subsidies) \\
\hline $\begin{array}{l}\text { [Byrne, Polonsky, } \\
\text { 2001] }\end{array}$ & $\begin{array}{l}\text { Regulatory encouragement and on infrastructure availability, economic, ideologi- } \\
\text { cal incentives }\end{array}$ \\
\hline [Delre, 2015] & $\begin{array}{l}\text { Hedonic, enjoyment of joint experience, social bonding, appreciation from others } \\
\text { (comparing to when go to movies alone), internal (WOM), external (advertising) }\end{array}$ \\
\hline [Aral, Walker, 2014] & Word of mouth, social influence \\
\hline $\begin{array}{l}\text { [Bilgicer et al., } \\
\text { 2019] }\end{array}$ & Customer satisfaction \\
\hline [Susarla, Oh, 2012] & Desire for social conformity, homophily, and awareness diffusion \\
\hline $\begin{array}{l}\text { [Arora, Ter } \\
\text { Hofstede, Mahajan, } \\
\text { 2017] }\end{array}$ & $\begin{array}{l}\text { Free version and developer reputation to gain additional information and reduce } \\
\text { uncertainty. Hedonic, utilitarian motivation to adopt apps }\end{array}$ \\
\hline $\begin{array}{l}\text { [Berger, Schwarz, } \\
\text { 2011] }\end{array}$ & $\begin{array}{l}\text { Cues (accessibility - whether products are top of mind), public visibility, interest } \\
\text { (people may talk about interesting things as they make them seem interesting - } \\
\text { signalling identity) }\end{array}$ \\
\hline $\begin{array}{l}\text { [Wong, Turner, } \\
\text { Stoneman, 1996] }\end{array}$ & $\begin{array}{l}\text { Pursuance of "green" principles. Scepticism and shortcomings in green products } \\
\text { performance as a hurdle }\end{array}$ \\
\hline $\begin{array}{l}\text { [Rhouma, Zaccour, } \\
2017]\end{array}$ & $\begin{array}{l}\text { Internal incentives provided by the firm (marketing efforts) and by external } \\
\text { incentives that include all other factors not related to marketing expenditures }\end{array}$ \\
\hline $\begin{array}{l}\text { [Avci, Girotra, } \\
\text { Netessine, 2014] }\end{array}$ & $\begin{array}{l}\text { Utility maximization from owning a vehicle: utility from driving, range inconve- } \\
\text { nience, green utility, direct costs }\end{array}$ \\
\hline $\begin{array}{l}\text { [Goel, Goldstein, } \\
2014]\end{array}$ & $\begin{array}{l}\text { Social signal - propensity to do the action (clicking, registering, purchasing) } \\
\text { which has been done by a friend }\end{array}$ \\
\hline
\end{tabular}


Appendix (continued)

\begin{tabular}{|c|c|}
\hline $\mathbf{1}$ & 2 \\
\hline [Sood, Kumar, 2017] & Loyalty \\
\hline $\begin{array}{l}\text { [Parry, Kawakami, } \\
\text { 2017] }\end{array}$ & Collectivism \\
\hline $\begin{array}{l}\text { [Vodanovich, } \\
\text { Sundaram, Myers, } \\
\text { 2010] }\end{array}$ & $\begin{array}{l}\text { Influence of family and friends, a socially supportive network, and the level of } \\
\text { emotional support as well as feeling close and connected to others on a daily basis. } \\
\text { Information, community, and collaboration. Task-technology fit. Ease of use, flow. } \\
\text { Need to belong }\end{array}$ \\
\hline [Huang et al., 2018] & Externality, social learning \\
\hline $\begin{array}{l}\text { [Makinen, } \\
\text { Kanniainen, Peltola, } \\
2014]\end{array}$ & Testing the app for subsequent adoption \\
\hline $\begin{array}{l}\text { [Mohr, Sengupta, } \\
\text { Slater, 2014] }\end{array}$ & Perceived innovativeness \\
\hline [Heath et al., 2015] & $\begin{array}{l}\text { Reference dependence - consumers judge current innovations and product } \\
\text { experiences relative to reference states such as prior innovations and product } \\
\text { experiences. Consumer desires for comfort. Consumer desires for stimulation }\end{array}$ \\
\hline [Haenlein, 2013] & Network externality, homophily \\
\hline $\begin{array}{l}{[\text { Frey, Oberholzer- }} \\
\text { Gee, 1997] }\end{array}$ & Price incentives, extrinsic and intrinsic motivation, signalling (risk-signalling) \\
\hline $\begin{array}{l}\text { [Brass, Butterfield, } \\
\text { Skaggs, 1998] }\end{array}$ & Social effects \\
\hline $\begin{array}{l}\text { [Bollinger, } \\
\text { Gillingham, 2012] }\end{array}$ & $\begin{array}{l}\text { Social spillover, peer effects: visibility of the panel (image motivation), WOM } \\
\text { (information transfer) }\end{array}$ \\
\hline [Boyd, Mason, 1999] & Attractiveness of an innovation, beliefs (about attractivenes), personal need \\
\hline [Iyer, Kuksov, 2012] & $\begin{array}{l}\text { Shopping experience (environment, such as music, smell, color, entertainment, } \\
\text { education) }\end{array}$ \\
\hline [Yang et al., 2012] & WOM \\
\hline [Bass, 1969] & Contagion, imitation of innovators \\
\hline $\begin{array}{l}\text { [Zhao, Hoeffler, } \\
\text { Dahl, 2009] }\end{array}$ & Visualisation, self-referencing \\
\hline [Tapiero, 1983] & WOM, interaction, diffusion, advertising \\
\hline $\begin{array}{l}\text { [Van den Bulte, } \\
\text { Stremersch, 2004] }\end{array}$ & $\begin{array}{l}\text { Social-normative pressures, power distance (need to conform with the status } \\
\text { group) - social identity. Masculinity - the greater importance masuline cultures } \\
\text { attach to material possessions, the higher intrinsic tendency to adopt innovations. } \\
\text { Provision of complements }\end{array}$ \\
\hline $\begin{array}{l}\text { [Van den Bulte, } \\
\text { Lilien, 2001] }\end{array}$ & $\begin{array}{l}\text { Normative pressure, competitive concern (rivals ivho have adopted the innovation } \\
\text { might be able to gain a competitive edge unless one adopts as well), performance } \\
\text { network effect (the number of prior adoptions) }\end{array}$ \\
\hline [Taylor, Todd, 1995] & $\begin{array}{l}\text { Perception of relative advantage, compatibility and complexity, facilitating } \\
\text { conditions (time, money, technology) }\end{array}$ \\
\hline [So, Oh, Min, 2018] & $\begin{array}{l}\text { Price value, enjoyment (hedonic motivation), home benefits (home atmosphere), } \\
\text { authencity, novelty, social interaction, social influence, sharing economy ethos, } \\
\text { electronic WOM, trend affinity }\end{array}$ \\
\hline
\end{tabular}


Appendix (continued)

\begin{tabular}{|c|c|}
\hline 1 & 2 \\
\hline $\begin{array}{l}\text { [Sääksjärvi, Samiee, } \\
2011]\end{array}$ & $\begin{array}{l}\text { The degree of technological anxiety consumers experience when faced with such } \\
\text { products and how playful they feel when interacting with them. Positive emotions }\end{array}$ \\
\hline $\begin{array}{l}\text { [Godes, Mayzlin, } \\
\text { 2004] }\end{array}$ & WOM \\
\hline $\begin{array}{l}\text { [Iyengar, Van den } \\
\text { Bulte, Valente, } \\
\text { 2010a] }\end{array}$ & Volume of product usage, network ties \\
\hline $\begin{array}{l}\text { [Iyengar, Van den } \\
\text { Bulte, Valente, } \\
\text { 2010b] }\end{array}$ & $\begin{array}{l}\text { Social-normative considerations, social identity considerations, competitive } \\
\text { considerations, installed base effects }\end{array}$ \\
\hline $\begin{array}{l}\text { [Moreau, Lehmann, } \\
\text { Markman, 2001] }\end{array}$ & Consumers' existing category knowledge and innovation continuity \\
\hline $\begin{array}{l}\text { [Lambrecht, Seim, } \\
\text { Tucker, 2011] }\end{array}$ & Time (quicker) and money (savings) \\
\hline [Godes, 2011] & Riskiness of the product - risk reduction - contagion \\
\hline [Aral, 2011] & Network externality, product price \\
\hline $\begin{array}{l}\text { [Zemack-Rugar, } \\
\text { Moore, Fitzsimons, } \\
\text { 2017] }\end{array}$ & Non-compliance quilt \\
\hline $\begin{array}{l}\text { [Van den Bulte, } \\
\text { Joshi, 2007] }\end{array}$ & $\begin{array}{l}\text { Interest on new developments, enthusiasm for innovations vs risk aversion. Social } \\
\text { identity, social status }\end{array}$ \\
\hline $\begin{array}{l}\text { [Song, Parry, } \\
\text { Kawakami, 2009] }\end{array}$ & Availability of complementary products, innovation's usefulness and ease of use \\
\hline $\begin{array}{l}\text { [Langley et al., } \\
\text { 2012] }\end{array}$ & $\begin{array}{l}\text { Explicit recommendations or word of mouth, implicit social norms such as what a } \\
\text { person feels is expected of him or her, or visible behavior }\end{array}$ \\
\hline $\begin{array}{l}\text { [Peng, Dey, Lahiri, } \\
2014]\end{array}$ & Contagion \\
\hline $\begin{array}{l}\text { [Allaway et al., } \\
\text { 1994] }\end{array}$ & Word of mouth, visual stimuli \\
\hline $\begin{array}{l}\text { [Peng, Dey, Lahiri, } \\
\text { 2008] }\end{array}$ & $\begin{array}{l}\text { Advertising and promotional activities; self-service, where there is a transfer of } \\
\text { labor to the customer; the supplier provides an experience and the customer is } \\
\text { part of this context; the customer self-selects, using the supplier's prescribed } \\
\text { processes, to solve a particular problem; the customer and supplier engage in the } \\
\text { especially important activity of co- design of products. Emotion as one of the } \\
\text { three elements of the relationship experience }\end{array}$ \\
\hline [Nagle, 2018] & Learning \\
\hline $\begin{array}{l}\text { [Chua, Roth, } \\
\text { Lemoine, 2015] }\end{array}$ & $\begin{array}{l}\text { Country's cultural norms (e.g. prize for originality in the USA). Cultural tight- } \\
\text { ness is reflected in a society's institutional practices, influencing } \\
\text { individual-level cognition, motivation, and behaviors }\end{array}$ \\
\hline $\begin{array}{l}\text { [Mathur, Chun, } \\
\text { Maheswaran, 2016] }\end{array}$ & Self-signaling, other-signalling \\
\hline $\begin{array}{l}\text { [Faraji-Rad, } \\
\text { Melumad, Johar, } \\
\text { 2017] }\end{array}$ & $\begin{array}{l}\text { Desire for control. The more people desire control, the more likely they are to } \\
\text { avoid situations that require relinquishing control }\end{array}$ \\
\hline
\end{tabular}




\begin{tabular}{|c|c|}
\hline & Appendix (end) \\
\hline 1 & 2 \\
\hline$[\mathrm{He}, 2016]$ & Perfectionism, high standard, motivation to excel \\
\hline $\begin{array}{l}\text { [Li, Gordon, } \\
\text { Gelfand, 2017] }\end{array}$ & $\begin{array}{l}\text { Advertising in loose cultures: promotion of ideals, permissiveness, and norm } \\
\text { deviance. Advertising themes in tight cultures will emphasize prevention focus, } \\
\text { uniformity, and norm abidance. }\end{array}$ \\
\hline $\begin{array}{l}\text { [Han, Gershoff, } \\
2018]\end{array}$ & $\begin{array}{l}\text { Stand to benefit, goal progress, proximity, framing of goal associated activities, } \\
\text { and the presence of conflicting goals, mood maintenance }\end{array}$ \\
\hline $\begin{array}{l}\text { [Weaver, Hamby, } \\
2018 \text { ] }\end{array}$ & Social influence \\
\hline [Ajzen, 1991] & $\begin{array}{l}\text { Subjective norm, attitude, belief (salient beliefs: behavioral beliefs, normative } \\
\text { beliefs, control beliefs) }\end{array}$ \\
\hline $\begin{array}{l}\text { [Peres, Van den } \\
\text { Bulte, 2014] }\end{array}$ & $\begin{array}{l}\text { Positive externality of social contagion, WOM, social-normative acceptability, } \\
\text { legitimacy, concerns about social status, visual influence, exclusivity }\end{array}$ \\
\hline $\begin{array}{l}\text { [Lee, Ofek, } \\
\text { Steenburgh, 2017] }\end{array}$ & WOM, search advertising, mass-invite, peer-to-peer actions \\
\hline $\begin{array}{l}\text { [Murphy, Dweck, } \\
\text { 2016] }\end{array}$ & $\begin{array}{l}\text { Mindsets are important because they shape people's motivation. Praises }- \text { for } \\
\text { fixed minset, learning - for growth mindset. Self-enhancement through brand } \\
\text { signaling by fixed mindset, by process by growth mindset }\end{array}$ \\
\hline $\begin{array}{l}\text { [Kummitha, } \\
\text { Crutzen, 2017] }\end{array}$ & Improvement of quality of life \\
\hline $\begin{array}{l}\text { [Chatterjee, Kar, } \\
\text { Gupta, 2018] }\end{array}$ & $\begin{array}{l}\text { Satisfaction (when «use» is taken in a process sense), intentional attitude, infor- } \\
\text { mation quality, perceived information quality, perceived system quality, perceived } \\
\text { service quality, perceived intention to use IoT, perceived Users' satisfaction using } \\
\text { IoT, actual usage of IoT, perceived net benefit of IoT }\end{array}$ \\
\hline [Kumar et al., 2018] & $\begin{array}{l}\text { SDT (self-determination theory): two types of motivation i.e. extrinsic motivation } \\
\text { when people make decisions for a purpose; and intrinsic motivation when people } \\
\text { perform activities for fun and enjoyment. TAM (technology acceptance model): } \\
\text { usefulness and ease of use }\end{array}$ \\
\hline [Yeh, 2017] & Customer needs and values \\
\hline $\begin{array}{l}\text { [El-Haddadeha et } \\
\text { al., 2019] }\end{array}$ & $\begin{array}{l}\text { The perceived value of IoT is strongly influenced by empowerment, perceived } \\
\text { usefulness and privacy related issues }\end{array}$ \\
\hline $\begin{array}{l}\text { [Bjerkan, Nørbech, } \\
\text { Nordtømme, 2016] }\end{array}$ & $\begin{array}{l}\text { Tax exemptions, exemption from road tolling or bus lane access, purchase price. } \\
\text { Actual costs and cost perceptions, risks, technological conservatism, (unproven) } \\
\text { technological performance, unfamiliarity and lack of knowledge }\end{array}$ \\
\hline [Chong et al., 2018] & $\begin{array}{l}\text { The extent that cities are ready to include their citizens in shared governance, } \\
\text { there are multiple ways of collecting citizen input }\end{array}$ \\
\hline $\begin{array}{l}\text { [DeLone, McLean, } \\
2003 \text { ] }\end{array}$ & $\begin{array}{l}\text { System quality, information quality, service quality, usage, user satisfaction, net } \\
\text { benefit }\end{array}$ \\
\hline $\begin{array}{l}\text { [Viitanen, Kingston, } \\
\text { 2014] }\end{array}$ & Motivational force behind ICT - to eradicate human error, uncertainty \\
\hline $\begin{array}{l}\text { [Lee, Hancock, } \mathrm{Hu}, \\
2014]\end{array}$ & Empowerment, perceived usefulness, privacy \\
\hline $\begin{array}{l}\text { [Heidenreich, } \\
\text { Spieth, Petschnig, } \\
\text { 2017] }\end{array}$ & Innovativeness \\
\hline
\end{tabular}

PЖM 17 (3): 387-410 (2019) 


\section{REFERENCES}

Aina Y.A. 2017. Achieving smart sustainable cities with GeoICT support: The Saudi evolving smart cities. Cities (71): 49-58.

Ajzen I. 1991. The theory of planned behavior. Organizational Behavior and Human Decision Processes 50 (2): 179-211.

Allaway A. W., Black W. C., Richard M. D., Mason J. B. 1994. Evolution of a retail market area: An event-history model of spatial diffusion. Economic Geography 70 (1): 2340.

Allmendinger G., Lombreglia R. 2005. Four Strategies for the Age of Smart Services. Harvard Business Review. [Electronic resource]. https://hbr.org/2005/10/four-strategies-for-the-age-of-smart-services (accessed: 25.09 .2019 ).

Anthopoulos L. 2017. Smart utopia VS smart reality: Learning by experience from 10 smart city cases. Cities (63): 128-148.

Aral S. 2011. Identifying social influence: A comment on opinion leadership and social contagion in new product diffusion. Marketing Science 30 (2): 217-223.

Aral S., Walker D. 2011. Creating social contagion through viral product design: A randomized trial of peer influence in networks. Management Science 57 (9): 1623-1639.

Aral S., Walker D. 2014. Tie strength, embeddedness, and social influence: A large-scale networked experiment. Management Science 60 (6): 1352-1370.

Ariely D., Gneezy U., Haruvy E. 2017.Social norms and the price of zero. Journal of Consumer Psychology 28 (2): 180-191.

Arora S., Ter Hofstede F., Mahajan V. 2017. The implications of offering free versions for the performance of paid mobile apps. Journal of Marketing 81 (6): 62-78.

Avci B., Girotra K., Netessine S. 2014. Electric vehicles with a battery switching station: Adoption and environmental impact.Management Science 61 (4): 772-794.

Bass F. M. 1969. A new product growth for model consumer durables. Management Science 15 (5): 215-227.

Beresteanu A., Li Sh. 2011. Gasoline prices, government support, and the demand for hybrid vehicles in the United States. International Economic Review 52 (1): 161-182.

Berger J., Schwarz E. M. 2011. What drives immediate and ongoing word of mouth? Journal of Marketing Research 48 (5): $869-$ 880.

Bilgicer T., Jedidi K., Lehmannc D. R., Neslin S. A. 2019. Social contagion and customer adoption of new sales channels. Journal of Retailing 91 (2): 254-271.

Bjerkan K. Y., Nørbech T. E., Nordtømme M. E. 2016. Incentives for promoting Battery Electric Vehicle (BEV) adoption in Norway. Transportation Research Part D (43): 169180.

Bollinger B., Gillingham K. 2012. Peer effects in the diffusion of solar photovoltaic panels. Marketing Science 31 (6): 900-912.

Boyd T. C., Mason C. H. 1999. The link between attractiveness of "extrabrand" attributes and the adoption of innovations. Journal of the Academy of Marketing Science 27 (3): 306-319.

Brass D. J., Butterfield K. D., Skaggs B. C. 1998. Relationships and unethical behavior: A social network perspective. The Academy of Management Review 23 (1): 14-31.

Byrne M. R., Polonsky M. J. 2001. Impediments to consumer adoption of sustainable transportation Alternative fuel vehicles. International Journal of Operations and Production Management 21 (12): 1521-1538.

Camero A., Alba E. 2019. Smart city and information technology: A review. Cities (93): 84-94.

Caragliu A., Del Bo C., Nijkamp P. 2011. Smart cities in Europe. Journal of Urban Technology 18 (2): 65-82.

Chatfield A.T., Reddick C.G. 2018. A framework for Internet of Things-enabled smart government: A case of IoT cybersecurity policies and use cases in U.S. federal government. Government Information Quarterly 36 (2): 346-357.

Chatterjee Sh., Kar A.K., Gupta M.P. 2018. Success of IoT in smart cities of India: An empirical analysis. Government Information Quarterly (35): 349-361. 
Chong M., Habib A., Evangelopoulos N., Park H.W. 2018. Dynamic capabilities of a smart city: An innovative approach to discovering urban problems and solutions. Government Information Quarterly (35): 682-692.

Chorus C.G., Koetse M.J., Hoen A. 2013. Consumer preferences for alternative fuel vehicles: Comparing a utility maximization and a regret minimization model. Energy Policy (61): 901-908.

Chua R. Y. J., Roth Y., Lemoine J.-F. 2015. The impact of culture on creativity: How cultural tightness and cultural distance affect global innovation crowdsourcing work. Administrative Science Quarterly 60 (2): 189-227.

Costa E. M., Oliveira Á.D. 2017. Humane smart cities. In: R. Frodeman, J. Klein, and R. Pacheco (eds). The Oxford Handbook of Interdisciplinarity (pp.228-240). Oxford University Press: Oxford.

Dameri R.P. 2013. Searching for smart city definition: A comprehensive proposal. International Journal of Computers and Technology 11 (5): 2544-2551.

DeLone W. H., McLean E. R. 2003. The Delone and Mclean model of information systems success: A ten-year update. Journal of Management Information Systems 19 (4): 9-30.

Delre S. A. 2015. The effects of shared consumption on product life cycles and advertising effectiveness: The case of the motion picture market. Journal of Marketing Research 53 (4): 2-94.

Edinger-Schons L. M., Sipila J., Sen S., Mende G., Wieseke J. 2018. Are two reasons better than one? The role of appeal type in consumer responses to sustainable products. Journal of Consumer Psychology 28 (4): 644-664.

El-Haddadeha R., Weerakkody V., Osmani M., Thakker D., Kapoor K. K. 2019. Examining citizens' perceived value of internet of things technologies in facilitating public sector services engagement. Government Information Quarterly 36 (2): 310-320.

Faraji-Rad A., Melumad Sh., Johar G. V. 2017. Consumer desire for control as a barrier to new product adoption. Journal of Consumer Psychology 27 (3): 347-354.
Fernandez-Anez V., Fernández-Güel J. M., Giffinger R. 2018. Smart City implementation and discourses: An integrated conceptual model. The case of Vienna. Cities (78): 4-16.

Forbes. 2018. The Smartest Cities in the World in 2018. [Electronic resource]. https:// www.forbes.com/sites/iese/2018/07/13/ the-smartest-cities-in-the-world-in-2018/ (accessed: 10.09.2019).

Frattini F., Bianchi M., De Massis A., Sikimic U. 2014. The role of early adopters in the diffusion of new products: Differences between platform and nonplatform innovations. Journal of Product Innovation Management 31 (3): 466-488.

Frey B.S., Oberholzer-Gee F. 1997. The Cost of Price Incentives: An empirical analysis of motivation crowding-out. The American Economic Review 87 (4): 746-755.

Giffinger R., Fertner C., Kramar H., Kalasek R., Pichler-Milanović N., Meijers E. 2007. Smart Cities. Ranking of European Medium-Sized Cities. Final Report. Centre of Regional Science: Vienna UT.

Godes D., Mayzlin D. 2004. Using online conversations to study word-of-mouth communication. Marketing Science 23 (4): 545560.

Godes D. 2011. Invited comment on "Opinion leadership and social contagion in new product diffusion". Marketing Science 30 (2): 224-229.

Goel Sh., Goldstein D. G. 2014. Predicting individual behavior with social networks. Marketing Science 33 (1): 82-93.

Goncalves G., Oliveira T., Cruz-Jesus F. 2018. Understanding individual-level digital divide: Evidence of an African country. Computers in Human Behavior (87): 276-291.

Graham-Rowe E., Gardner B., Abraham Ch., Skippon S., Dittmar H., Hutchins R., Stannard J. 2012. Mainstream consumers driving plug-in battery-electric and plug-in hybrid electric cars: A qualitative analysis of responses and evaluations. Transportation Research Part A 46 (1): 140-153.

Greer C. R., Lei D. 2012. Collaborative innovation with customers: A review of the literature and suggestions for future research. International Journal of Management Reviews 14 (1): 63-84. 
Hackbarth A., Madlener R. 2013. Consumer preferences for alternative fuel vehicles: A discrete choice analysis. Transportation Research Part D: Transport and Environment (25): 5-17.

Haenlein M. 2013. Social interactions in customer churn decisions: The impact of relationship directionality. International Journal of Research in Marketing 30 (3): 236248.

Hall R.E., Bowerman B., Braverman J., Taylor J., Todosow H. 2000. The Vision of a Smart City. 2nd International Life Extension Technology Workshop: Paris.

Han E., Gershoff A. D. 2018. Lots to do or lots of ways to do it? The role of mood and mind-set on goal motivation. Journal of Consumer Psychology 29 (2): 187-206.

Harrison C., Eckman B., Hamilton R., Hartswick P., Kalagnanam J., Paraszczak J., Williams P. 2010. Foundations for smarter cities. IBM Journal of Research and Development 54 (4): 1-16.

Heath T. B., Chatterjee S., Basuroy S., Hennig-Thurau T., Kocher B. 2015. Managing innovation sequences over iterated offerings: Developing and testing a relative innovation, comfort, and stimulation framework of consumer responses. Journal of Marketing 79 (6): 71-93.

He X. 2016. When perfectionism leads to imperfect consumer choices: The role of dichotomous thinking. Journal of Consumer Psychology 26 (1): 98-104.

Heidenreich S., Spieth P., Petschnig M. 2017. Ready, steady, green: Examining the effectiveness of external policies to enhance the adoption of eco-friendly innovations. Jour nal of Product Innovation Management 34 (3): 343-359.

Huang Y., Gokpinar B., Tang C. S., Yoo O. S. 2018. Selling innovative products in the presence of externalities. Production and Operations Management 27 (7): 1236 1250.

IHS Markit. 2014. Smart Cities to Rise Fourfold in Number from 2013 to 2025. [Electronic resource]. https://news.ihsmarkit. com/press-release/design-supply-chain-me$\mathrm{dia} /$ smart-cities-rise-fourfold-number-20132025 (accessed: 10.09.2019).
ISO. 2019. ISO 37122:2019 Sustainable Cities and Communities - Indicators for Smart Cities. [Electronic resource]. https://www. iso.org/standard/69050.html (accessed: 10.09.2019).

Iyengar R., Van den Bulte C., Valente T.W. 2010a. Opinion leadership and social contagion in new product diffusion. Marketing Science 30 (2): 195-212.

Iyengar R., Van den Bulte C., Valente T.W. 2010b. Further reflections on studying social influence in new product diffusion. Marketing Science 30 (2): 1-9.

Iyer G., Kuksov D. 2012. Competition in consumer shopping. Marketing Science 31 (6): 913-933.

Janowski T., Estevez E., Baguma R. 2018. Platform governance for sustainable development: Reshaping citizen-administration relationships in the digital age. Government Information Quarterly 35 (4): 1-16.

Jensen A. F., Cherchi E., Mabit S.L. 2013. On the stability of preferences and attitudes before and after experiencing an electric vehicle. Transportation Research Part D: Transport and Environment (25): 24-32.

Kumar H., Singh M.K., Gupta M.P., Madaan J. 2018. Moving towards smart cities: Solutions that lead to the smart city transformation. Technological Forecasting and Social Change. In press.

Kummitha R. K.R., Crutzen N. 2017. How do we understand smart cities? An evolutionary perspective. Cities (67): 43-52.

Lambrecht A., Seim K., Tucker C. 2011. Stuck in the Adoption Funnel: The effect of interruptions in the adoption process on usage. Marketing Science 30 (2): 355-367.

Langley D.J., Bijmolt T.H.A., Ortt J.R., Pals N. 2012. Determinants of social contagion during new product adoption. Journal of Product Innovation Management 29 (4): 623-638.

Lee J.H., Hancock M. G., Hu M. 2014. Towards an effective framework for building cities: Lessons from Seoul and San Francisco. Technological Forecasting and Social Change (89): 80-99.

Lee J., Lee H. 2014. Developing and validating a citizen-centric typology for smart 
city services. Government Information Quarterly 31 (1): 93-105.

Lee C., Ofek E., Steenburgh T. J. 2017. Personal and social usage: The origins of active customers and ways to keep them engaged. Management Science 64 (6): 2473-2495.

Lee T.(D.), Park H., Lee J. 2018. Collaborative accountability for sustainable public health: A Korean perspective on the effective use of ICT-based health risk communication. Government Information Quarterly 36 (2): 226-236.

Li R., Gordon S., Gelfand M.J. 2017. Tightness-looseness: A new framework to understand consumer behavior. Journal of Consumer Psychology 27 (3): 377-391.

Lim Ch., Kimb K.-J., Maglioc P. P. 2018. Smart cities with big data: Reference models, challenges, and considerations. Cities (82): 86-99.

Makinen S. J., Kanniainen J., Peltola I. 2014. Investigating adoption of free beta applications in a platform-based business ecosystem. Journal of Product Innovation Management 31 (3): 451-465.

Manville C., Cochrane G., Cave J., Millard J., Pederson J.K., Thaarup R.K., Liebe A., Wissner M., Massink R., Kotterink B. 2014. Mapping smart cities in the UE. Study. Directorate-General for Internal Policies. Policy Department A: Economic and Scientific Policy. European Parliament: Brussels.

Mathur P., Chun H.H., Maheswaran D. 2016. Consumer mindsets and self-enhancement: Signaling versus learning. Journal of Consumer Psychology 26 (1): 142-152.

Moreau C.P., Lehmann D.R., Markman A.B. 2001. Entrenched knowledge structures and consumer response to new products. Journal of Marketing Research 38 (1): 14-29.

Morvinsky C., Amir O., Muller E. 2017. "Ten million readers can't be wrong!", or Can they? On the role of information about adoption stock in new product trial. Marketing Science 36 (2): 290-300.

Murphy M. C., Dweck C. S. 2016. Mindsets shape consumer behavior. Journal of Consumer Psychology 26 (1): 127-136.

Nagle F. 2018. Learning by contributing: Gaining competitive advantage through contri- bution to crowdsourced public goods. Organization Science 29 (4): 569-587.

Nilssen M. 2018. To the smart city and beyond? Developing a typology of smart urban innovation. Technological Forecasting and Social Change 142 (C): 98-104.

OneNYC 2050. 2019. Building a Strong and Fair City (1). [Electronic resource]. https:// onenyc2050.com/ (accessed: 05.09.2019).

Parry M.E., Kawakami T. 2017. The encroachment speed of potentially disruptive innovations with indirect network externalities: The case of e-readers. Journal of Product Innovation Management 34 (2): 141-158.

Peng G., Dey D., Lahiri A. 2014. Healthcare IT adoption: An analysis of knowledge transfer in socioeconomic networks. Journal of Management Information Systems 31 (3): 7-34.

Peres R., Muller E., Mahajan V. 2010. Innovation diffusion and new product growth models: A critical review and research directions. International Journal of Research in Marketing (27): 91-106.

Peres R., Van den Bulte C. 2014. When to When to take or forgo new product exclusivity: Balancing protection from competition against word-of-mouth spillover. Journal of Marketing 78 (2): 83-100.

Porter M.E., Heppelmann J.E. 2014. How smart, connected products are transforming competition. Harvard Business Review. [Electronic resource]. https://hbr. org/2014/11/how-smart-connected-products-are-transforming-competition (accessed: 05.09.2019).

Prensky M. 2001. Digital natives, digital immigrants. On Horizon 9 (5): 1-2.

Rhouma T. B., Zaccour G. 2017. Optimal marketing strategies for the acquisition and retention of service subscribers. Management Science 64 (6): 2609-2627.

Rogers E. M. 2003. Diffusion of Innovations. Free Press: N.Y.

Ruhlandt R.W.S. 2018. The governance of smart cities: A systematic literature review. Cities (81): 1-23.

Sääksjärvi M., Samiee S. 2011. Assessing multifunctional innovation adoption via an integrative model. Journal of the Academy of Marketing Science 39 (5): 717-735. 
So K.K.F., Oh H., Min S. 2018. Motivations and constraints of Airbnb consumers: Findings from a mixed-methods approach. Tour ism Management (67): 224-236.

Song M., Parry M. E., Kawakami T. 2009. Incorporating network externalities into the technology acceptance model. Journal of Product Innovation Management (26): 291-307.

Sood A., Kumar V. 2017. Analyzing client profitability across diffusion segments for a continuous innovation. Journal of Market ing Research 54 (6): 932-951.

Sun T.Q., Medaglia R. 2019. Mapping the challenges of Artificial Intelligence in the public sector: Evidence from public healthcare. Government Information Quarterly 36 (2): 368-383.

Susarla A., Oh J.-H. 2012. Social Networks and the Diffusion of User-Generated Content: Evidence from YouTube. Information Systems Research 23 (1): 23-41.

Tapiero C. S. 1983. Stochastic diffusion models with advertising and word-of-mouth effects. European Journal of Operational Research 12 (4): 348-356.

Taylor Sh., Todd P. 1995. Decomposition and crossover effects in the theory of planned behavior: A study of consumer adoption intentions. International Journal of Research in Marketing 12 (2): 137-155.

Trencher G. 2019. Towards the smart city 2.0: Empirical evidence of using smartness as a tool for tackling social challenges. Technological Forecasting and Social Change (142): 117-128.

Van den Bulte C., Joshi Y. V. 2007. New product diffusion with influentials and imitators. Marketing Science 26 (3): 400-121.

Van den Bulte C., Lilien G. L. 2001. Medical Innovation Revisited: Social contagion versus marketing effort. American Journal of Sociology 106 (5): 1409-1435.

Van den Bulte C., Stremersch S. 2004. Social contagion and income heterogeneity in new product diffusion: A meta-analytic test. Marketing Science 23 (4): 530-544.

Van den Buuse D., Kolk A. 2018. An exploration of smart city approaches by international ICT firms. Technological Forecasting and Social Change 142: 220-234.
Viitanen J., Kingston R. 2014. Smart cities and green growth: outsourcing democratic and environmental resilience to the global technology sector. Environment and Planning A: Economy and Space 46 (4): 803819.

Vodanovich Sh., Sundaram D., Myers M. 2010. Digital natives and ubiquitous information systems. Information Systems Research $\mathbf{2 1}$ (4): 711-723.

Watts D.J., Dodds P.Sh. 2007. Influentials, networks, and public opinion formation. Journal of Consumer Research (34): 441458.

Weaver K., Daniloski K., Schwarz N., Cottone K. 2015. The role of social comparison for maximizers and satisficers: Wanting the best or wanting to be the best? Journal of Consumer Psychology 25 (3): 372-388.

Weaver K., Hamby, A. 2018. The sounds of silence: Inferences from the absence of word-of-mouth. Journal of Consumer Psychology 29 (1): 3-21.

Wirtz B.W., Weyerer J.C., Schichtel F. T. 2018. An integrative public IoT framework for smart government. Government Information Quarterly 36 (2): 333-345.

Woetzel J., Kuznetsova E. 2018. Smart City Solutions: What Drives Citizen Adoption around the Globe? McKinsey Center for Government. McKinsey\&Company.

Woetzel J., Remes J., Boland B., Lv K., Sinha S., Strube G., Means J., Law J., Cadena A., Von der Tann V. 2018. Smart Cities: Digital Solutions for a More Livable Future. Report. McKinsey Global Institute.

Wong V., Turner W., Stoneman P. 1996. Marketing strategies and market prospects for environmentally-friendly consumer products. British Journal of Management 7 (3): 263-281.

Yang S., Hu M., Winer R.S., Assael H., Chen X. 2012. An empirical study of wordof-mouth generation and consumption. Marketing Science 31 (6): 952-963.

Yeh H. 2017. The effects of successful ICTbased smart city services: From citizens' perspectives. Government Information Quarterly (34): 556-565.

Yigitcanlar T., Kamruzzaman Md., Buys L., Ioppolo G., Sabatini-Marques J., Moreira 
da Costa E., Yun J. J., 2018. Understanding 'smart cities': Intertwining development drivers with desired outcomes in a multidimensional framework. Cities (81): 145-160.

Zemack-Rugar Y., Moore S. G, Fitzsimons G.J. 2017. Just do it! Why committed consum- ers react negatively to assertive ads. Journal of Consumer Psychology 27 (3): 287301.

Zhao M., Hoeffler S., Dahl D. 2009. The role of imagination - focused visualization on new product evaluation. Journal of Marketing Research (XLVI): 46-55.

Initial Submission: September 15, 2019 Final Version Accepted: October 15, 2019

\section{Почелу потребители выбирают с «улол»? Вызовы принятия потребителяли решений улньх городов}

\section{Ю. А. Мальченко, М. М. Слирнова}

Институт «Высшая школа менеджмента» Санкт-Петербургского государственного университета, Россия

В связи с распространением цифровых технологий многие города начали поддерживать умные решения для эффективного использования ограниченных ресурсов. Развитие умных городов требует тесного сотрудничества между органами управления, бизнесом и сообществом потребителей для разработки решений для различных заинтересованных сторон. Несмотря на то что большинство исследований в этой области сосредоточено на цифровой стороне умных решений, набирает обороты и подход, ориентированный в первую очередь на интересы жителей городов как пользователей данных решений. Однако область принятия жителями умных городских решений недостаточно изучена. На практике исследования ограничиваются предложениями использовать обратную связь с потребителями, при этом факторы, стимулирующие потребителей принимать решения умных городов, не были выявлены. Данная работа направлена на создание теоретической основы для дальнейших исследований, включающей интегрированный и ориентированный на жителей городов подход «снизу вверх». Статья объединяет идеи из существующих исследований, посвященных внедрению инноваций и созданию решений для умных городов. Предлагаемая теоретическая классификация сопровождается предложениями для будущих исследований, посвященных цифровым «аборигенам» как будущим потребителям умных решений.

Ключевые слова: решения умного города, внедрение инноваций, принятие потребителем, готовность к принятию решений, гражданско-ориентированный подход, подход «снизу вверх». JEL: M31.

For citation: Malchenko Ya. A., Smirnova M. M. 2019. What drives consumers smart? The challenge of adoption of smart city solutions. Russian Management Journal 17 (3): 387-410.

Статья поступила в редакцию 15 сентября 2019 г. Принята к публикаиии 15 октября 2019 г. 